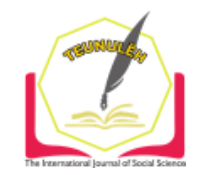

Jurnal Ilmiah Teunuleh

The International Journal of Social Sciences

Vol. 1, Issue. 1, Sept 2020

E-ISSN: 2746-4393

\title{
DISCOVERY LEARNING LEARNING ANALYSIS IN THE 2013 CURRICULUM IN PRIVATE VOCATIONAL SCHOOL OF SUAK PANDAN STATE SCHOOL, KECAMATAN SAMATIGA, WEST ACEH DISTRICT
}

\author{
Riski Syahwal Usm ${ }^{\mathbf{1}}$ \\ STKIP Bina Bangsa Meulaboh \\ Email: riskisyahwal@gmail.com \\ Mardhatillah² \\ STKIP Bina Bangsa Meulaboh \\ Email: Mardhatillah.atjeh@gmail.com
}

\begin{abstract}
The formulation of the research problem is how is discovery learning in the 2013 curriculum at Suak Pandan Elementary School, Samatiga District, West Aceh Regency. The purpose of this study was to determine discovery learning in the 2013 curriculum at Suak Pandan Elementary School, Samatiga District, West Aceh Regency. This type of research is descriptive (descriptive research). The subjects in the research were 2 grade teachers of SD Negeri Suak Pandan. The research time was in August 2019. The data collection techniques were: observation, interview and documentation. Instruments such as: observation sheets, interview sheets and documentation sheets. Based on the results of the study, the study concluded that discovery learning in the 2013 curriculum at the Suak Pandan Elementary School, Samatiga District, West Aceh Regency, seen from the teacher having carried out his profession as a highly competent teacher in the field that was managed by applying competency assessment in the learning process while learning Discovery learning has been implemented very well, where each teacher carries out the steps of discovery learning where in learning activities students learn actively to find concepts, the meaning of previous knowledge then combine new knowledge and existing knowledge and apply it during the learning process.
\end{abstract}

Keywords:Analysis, Discovery learning, Curriculum 2013.

\section{A. Introduction}

The curriculum is a set of plans and arrangements regarding the objectives, content and learning materials that are used as guidelines for implementing learning 


\section{Risky Syahwal Usm; Mardhatillah}

activities to achieve certain educational goals. The curriculum is one element that contributes to the quality of quality learning. To improve the quality of quality learning, curriculum refinement and refinement are always carried out continuously in line with the demands of educational needs and conditions. (Kemendikbud, 2013: 6)

Learning in the 2013 Curriculum demands a change in the application of the learning process to be implemented. Not only in the form of learning that is shown, but the good and bad behavior of students are also monitored in the 2013 curriculum and improve morale. Thus, the achievement of process standards to improve the quality of education can be started from analyzing each component that can shape and influence the learning process. The learning process will be meaningful if the activities carried out make students interested in learning activities.

Discovery Learning refers to the learning theory which is defined as the learning process that occurs when students are not presented with the lesson in its final form, but students are expected to organize themselves. The learning process must use learning to be able to make learning meaningful in a teaching and learning process. One of the lessons contained in the 2013 curriculum is Discovery Learning. In applying Discovery Learning, the teacher acts as a guide by giving students the opportunity to learn actively, as the teacher's opinion must be able to guide and direct student learning activities according to their goals. (Mulyatiningsih, 2012: 235)

The use of the 2013 curriculum does not have obstacles. These constraints include teachers who are less creative in using learning models, learning activities seem monotonous which results in a sense of curiosity about learning and student learning outcomes will be low. This is very concerning, especially in lessons that require a basic understanding of the concepts that are the basis of learning, so the child's curiosity must be increased by using creative, innovative, and inventive learning models. Discovery learning will increase children's curiosity about something they are learning, so that children will discover the facts themselves and then find the basic understanding they need.

Based on observations in thematic learning. The author conducted research on the theme of where I live, sub-theme of the uniqueness of the area where I live in class IV semester 2 of SD Negeri Suak Pandan. SD Negeri Suak Pandan has used the 2013 curriculum, so this observation is very relevant to the problems that the authors convey above. The study encountered several problems such as the teacher's incorrect choice of learning to use, so that students' curiosity about the learning material 
being studied was very low and then there was a misunderstanding of the concept in children. This causes it to often be out of sync with what the teacher says and this certainly results in poor learning outcomes.

In overcoming the above problems, it is necessary to carry out learning that can support the understanding of learning concepts properly, including the use of Discovery Learning which is part of student-centered learning. Student- centered learning (Student Centered Leaning), students are expected to be active and independent participants in the learning process, who are responsible and take the initiative to recognize their learning needs, find sources of information to answer their needs, build and present their knowledge based on needs and the source it found. (Eko Wahjudi, 2015: 2)

Discovery Learning is a strategy used to solve problems intensively under teacher supervision. With the Discovery Learning learning, it is hoped that it can help students find problems that can be solved by themselves. Discovery Learning has characteristics that become from other learning, namely: involving students actively in all stages of learning from the initial stage to the final stage, learning is always connected to the context of student life, learning takes place in collaborative and cooperative learning communities, teachers and students are equally actively involved during the learning process, transfer information concepts, present life-long learning concepts. (Yunus, 2013: 152)

Discovery Learning learning directs students to understand concepts, meanings, and relationships, through an intuitive process to finally arrive at a conclusion. Concept discovery is not presented in the final form, but students are encouraged to identify what they want to know and continue by looking for information themselves then organize or construct who they know and understand in a final form. This happens when students are involved, especially in the use of mental processes to find some concepts and principles. (Eko Wahjudi, 2015: 2)

It is clear that the problems described above have arisen. The author concludes that the main cause in this problem is the teacher's reticence in using learning so that the low curiosity of students in learning has an impact on low learning outcomes. The use of appropriate learning models in learning will have an impact on the success of learning as a whole, this of course must be supported by creative teachers in applying the learning model.

The choice of learning requires a teacher's carefulness, because learning must be adapted to the material to be used in the learning process. This is based on the fact that 
not all learning is compatible with learning materials which makes it imperative to first assess the learning model of the material to be used.

Responding to the above problems, being a creative elementary school teacher and choosing the right learning model is the best weapon in advancing education in Indonesia, because one of the goals of education in Indonesia is to improve the quality of human resources in Indonesia to become complete human beings, namely an integrated person. , productive, creative and has a leadership attitude and scientific insight as a responsible citizen.

According to the reality of the problems described above, the researcher wants to design a lesson that can stimulate students' curiosity in the sub-theme of the uniqueness of the area where I live so that it can improve student learning outcomes, namely by using Discovery Learning. Related to the above problems, the researcher is interested in conducting this research with the title "Analysis of Discovery Learning in the 2013 Curriculum at Suak Pandan Elementary School, Samatiga District, West Aceh Regency".

\section{B. Method}

This research uses qualitative research, which seeks to understand and interpret the meaning of an event, interaction and human behavior in certain situations according to the perspective of the researcher. This approach is used because the data obtained is descriptive data in the form of written and spoken words from people. -people and in the form of documents or observed behavior.

This type of research is descriptive (descriptive research) or a study aimed at describing existing phenomena that are taking place at present or in the past. This study does not manipulate or change the independent variables but describes the conditions as they are.

This research was conducted at SD Negeri Suak Pandan, West Aceh Regency. The time of this research was conducted in August 2019. In qualitative research methods, data is collected using several techniques, namely: interviews, observation and documentation.

1. Interview

Interviews are a form of direct communication between researchers and informants (data sources), communication takes place in the form of face-to-face 
questions and answers. The interview in this study was a grade IV teacher at SD Negeri Suak Pandan.

\section{Observation}

Observation is a method or research method which is the only method available and is able to unify various kinds of information.

3. Documentation

Documents are records of events that have passed. Documents can be in the form of writings, pictures, or monumental works of a person (Sugiyono, 2008:

329). In this study, documents can be used as additional information and it is hoped that this documentation technique can strengthen the information that researchers have obtained.

Qualitative data analysis techniques are efforts made by working with data, organizing data, sorting them into manageable units, synthesizing them, looking for and finding patterns, finding what can be told to others (Moleong, 2013: 248).

This research analysis process begins with:

1. Examining all data begins with examining all available sources, namely from interviews, documentation and observations. After reading, studying and analyzing it turns out that the data obtained is still random, so the next step is to conduct data reduction.

2. Data reduction is a process of assessment, formulation of attention, simplification, validation and transformation of written data. This arrangement is manifested in a collection of information that allows the conclusion of observations to be drawn.

3. Data that has been collected from field studies which include interviews, documentation and observation followed by note-taking, investigation and editing which are finally grouped under the same characteristics and then analyzed descriptively so that they are easy to understand.

4. Withdrawing conclusions and verification Conclusions in qualitative research are new findings in the form of a description or description of an object that was previously dim or unclear, so that after being examined it becomes clearer. These can be casual or interactive relationships, hypotheses or theories.

\section{Finding and Discussion}




\section{Risky Syahwal Usm; Mardhatillah}

Based on observations with mother $\mathrm{S}$, the fourth grade guardian of SD Negeri Suak Pandan, among others:

Students show a happy attitude in discovery learning, yes, students show a happy attitude in discovery learning, because this is the first time students feel learning using this learning model. In that case, we can see students by increasing their motivation to learn because the way of delivering teachers is more varied and of higher quality.

Students are active in discovery learning, yes, students are very active in discovery learning, because previously students were not active in learning after the teacher applied discovery learning, then it was seen that the students' activeness in learning. Because students are required to be creative themselves in terms of learning and students are free to issue their ideas in a lesson that can increase student motivation.

Students pay attention to the teacher's explanation of discovery learning, yes, students always pay attention to the teacher's explanation of discovery learning, but there are some students who do not pay attention to the teacher's explanation in the teaching and learning process because they are busy with their own affairs, such as annoying friends and making noise. There are also students who are not responsive to a lesson the teacher delivers, because students have a weak $I Q$.

Students ask questions to the teacher about discovery learning, yes, students always ask questions to the teacher on material that they do not understand in discovery learning and there are also some students who are not brave or are still embarrassed to ask questions. Because they still thought that what they conveyed was wrong and were angry because of that the students were not brave enough to ask questions.

Students answer questions from the teacher in the discussion of discovery learning, yes, there are some students who are courageous and active in answering teacher questions in discovery learning, because previously students were a bit shy in asking questions. Students already understand what the teacher says and they ask what they don't know to understand.

Students do assignments from the teacher, yes, students do the assignments given by the teacher and they ask questions that they don't understand, because they previously worked on questions but they don't dare to ask anymore about the questions given by the teacher. Because students are very happy if given additional tasks that can 
be done at home and they can do it while playing with friends and exchange ideas in solving a problem.

Based on the results of research interviews with mother $S$, the fourth grade guardian of SD Negeri Suak Pandan, among others:

What is said by Discovery Learning in the opinion of the teacher, Discovery Learning is a method of discovery, because students must be able to find information on their own from the specified material. In practice, students must be able to find their own way so that the products produced can be completed in accordance with predetermined conditions. So students must develop not to be fixated on what I teach.

What are the strategies (teacher activities and student activities) so that Discovery Learning learning can be carried out properly, teacher activities: guiding, before practice begins explaining how to work to make cleavage first then after the teacher's students supervise student practice Student activities: pay attention to teacher explanations, discuss with friends and do practical assignments given by the teacher, because previously the learning that the teacher applied was only a lecture method that did not vary.

What is the goal to be achieved by using Discovery Learning in Curikulu, 2013, the goal is that learning is more effective and students are more independent, because with discovery learning they can come up with their own ideas.

What are the method steps that you carry out in the teaching and learning process with Discovery Learning, the steps are in accordance with the discovery learning syntax, namely providing stimulation, identifying problems, collecting data, processing data, proving and drawing conclusions, because with discovery learning steps, student activity will appear.

What is the strategy you do to design the feasibility of observing, asking, experimenting, associating, communicating and creating, the strategy is implemented according to the plan but must pay attention to the student's condition, because by looking at the student's condition the teacher can make a strategy that the teacher plans.

What do the teachers think about students' attitudes after implementing Discovery Learning, students enjoy learning more and are more active, because before the teacher applies discovery learning they look bored in the lesson, some sleep while the teacher explains.

How do you prepare (physical, mental and material) before carrying out the Discovery Learning lesson, physical readiness: body condition must be healthy and have 


\section{Risky Syahwal Usm; Mardhatillah}

a polite and neat appearance, mentally: do not mix personal problems with teaching and must focus and always think positive, material: RPP must be ready, prepare media such as fragments for student work samples and jobsheets so that student practice is directed, prepare materials to be used.

Changes in the education unit level curriculum to the 2013 curriculum caused some teachers to not understand the meaning of the 2013 curriculum. Where it is known that teachers play an important role in the 2013 curriculum, teachers are expected to carry out learning with a scientific approach by applying the learning model recommended by the government. Teacher competence is an important factor that a teacher must have, including aspects of knowledge, skills, thought processes, adjustment, and attitudes. Teacher competency standards are a measure set or required in the implementation of the 2013 curriculum.

Based on the results of observations with the teacher, mother $\mathrm{S}$, guardian of class IV SD Negeri Suak directly during the learning process, the learning used in this study is discovery learning, before starting learning, the teacher first designed the lesson plan lesson plan according to the demands of the 2013 curriculum which included the steps learning to apply and determine the learning to be used in learning that is tailored to the material.

When the learning process takes place the teacher carries out learning in a structured manner where the delivery of the material is explained clearly based on the stages of the learning steps that have been made before starting learning. Observations that have been made during the learning process show an overview of teacher competency standards based on the aspects of knowledge, skills and behavior possessed by teachers that can affect the achievement of learning and educational goals in school.

In the 2013 curriculum there are four learning models, namely discovery learning, Inquiry learning, problem-based learning and project- based learning. The learning model is very influential for creating effective learning activities, so that teachers are required to be wise in determining the model to be used for a material to be taught.

Discovery learning is more often used, especially in SD Negeri Suak Pandan, because subjects in SD are included in groups of subjects that tend to master concepts or principles, therefore discovery learning is most often used in theory classes because it is adjusted to the conditions and material being taught. 
Based on the results of observations with the teacher, Ibu S, the fourth grade guardian of SD Negeri Suak, almost all components are fulfilled in learning based on the stages of discovery learning. Starting from preliminary activities where the teacher provides an overview through videos, pictures or in a daily environment that provides motivation to students in starting the teaching and learning process to the core activity which shows that there are activities that are dominated by students in a group discussion so that most participants students become active in responding to questions to other students. At the end of the closing lesson, the teacher directs students to give conclusions for each group and gives assignments according to the material that has been taught and does not forget the teacher directs students to learn the material to be taught next week.

The learning process gets a good response because it is adjusted to the conditions and characteristics of the students. Student activities take place effectively where students are more active in responding to learning so that the time in implementing learning for discussion in particular takes longer to complete so that learning objectives can be achieved.

After the learning stages were carried out well, the researchers conducted interviews with each subject with the aim of finding information related to the implementation of the 2013 curriculum-based learning model that has been applied in the learning process in the classroom which aims to be most effective so that the teaching and learning process runs conducive.

Based on the results of interviews with the teacher, Ibu S, class IV of SD Negeri Suak Pandan, directly after observing the teacher competency standards by looking at the implementation design of learning and learning based on the 2013 curriculum, it can be concluded that the 2013 curriculum, especially the 2013 curriculum-based learning, has been implemented well.

Bruner became very famous because he was more concerned with the learning process than learning outcomes, the method he used was the discovery learning method. Discovery learning from Bruner is a teaching model developed based on a cognitive view of learning and the principles of constructivity. (Simultaneously, 2013: 70)

In Bruner's theory with the discovery learning method, the drawback is that it cannot be used in all materials, only a few materials can be used with the discovery method. Learning theory according to J.S. Bruner is not much different from J. Piaget's theory. According to the theory of J.S. Bruner's best step in learning is to compile his 
presentation, because in the first step of learning concepts, understanding will be more inherent if activities that show the representation (model) of concepts are carried out by students themselves and between past lessons and what is learned must be related.

\section{Conclusion}

The conclusion of this study is based on the formulation of the problem, the results of research and discussion which shows that discovery learning in the 2013 curriculum at the Suak Pandan Elementary School, Samatiga District, West Aceh Regency, seen from the teacher who has carried out his profession as a teacher who is very competent in the subject being taught. by applying competency assessment in the learning process while discovery learning has been carried out very well, where each teacher carries out the steps in accordance with the discovery learning steps where in learning activities students learn actively in finding concepts, the meaning of previous knowledge and then combine new knowledge and existing knowledge and apply it as the learning process takes place.

\section{Bibliography}

Eko Wahjudi, 2015, Penerapan Discovery Learning Dalam Pembelajaran IPA Sebagai Upaya Untuk Meningkatkan Hasil Belajar Siswa Di SMP Negeri 1 Kalianget, Jurnal Lensa, Volume 5 Jilid I

Kementerian Pendidikan dan Kebudayaan, 2013, Kurikulum 2013; Rasional, Kerangka Dasar, Struktur, Implementasi, dan Evaluasi Kurikulum, Jakarta: Kemendikbud

Mulyatiningsih, 2012, Metode Penelitian Terapan Bidang Pendidikan, Bandung: Alfabeta Moleong, 2013, Metodologi Penelitian Pendidikan, Bandung: Remaja Rosdakarya

Simanjutak, 2013, Metode Mengajar Matematika, Jakarta: Rineka Cipta

Sugiyono, 2008, Metode Penelitian Kuantitatif dan Kualitatif dan R\&D, Bandung Alfabeta

Yunus, 2013, Desain Sistem Pembelajaran dalam Konteks Kurikulum2013, Bandung: Refika Aditama 